Jurnal Ilmiah Ibnu Sina, 6(2), Oktober 2021, 232-241

p-ISSN: 2502-647X; e-ISSN: 2503-1902

\title{
EFEKTIVITAS KOMBINASI PLASMA JET NON -THERMAL DAN SPRAY Aloe vera (L). Burm. $f$. PADA PENYEMBUHAN LUKA DIABETES
}

\author{
Ratih Arum Astuti ${ }^{1}$, Laela Hayu Nurani ${ }^{1 *}$, Eka Sakti Wahyuningtyas ${ }^{2}$, Iis \\ Wahyuningsih $^{1}$, Devi Kemala Dewi ${ }^{2}$, Isabella Meliawati Sikumbang ${ }^{2}$, \\ Nasruddin $^{3}$ \\ ${ }^{1}$ Universitas Ahmad Dahlan \\ ${ }^{2}$ Universitas Muhammadiyah Magelang \\ ${ }^{3}$ Universitas Muhammadiyah Semarang \\ *Email: laela.farmasi@pharm.uad.ac.id
}

Artikel diterima: 26 Juni 2021; Disetujui: 20 September 2021

DOI: https://doi.org/10.36387/jiis.v6i2.708

\begin{abstract}
ABSTRAK
Plasma jet non thermal dapat digunakan sebagai penyembuhan luka namun pengontrolan yang kurang tepat dapat menyebabkan akumulasi reactive oxygen spesies (ROS). Kombinasi dengan bahan alam memperbaiki efek sampingnya. Aloe vera mempunyai kemampuan dalam penyembuhan luka. Penelitian ini bertujuan untuk mengetahui efektivitas kombinasi plasma jet dan bahan alam yaitu sediaan spray larutan $A$. vera $1 \%$ pada mencit model luka diabetes dengan parameter kadar malondialdehid, rasio luas luka, dan profil darah. Penelitian ini menggunakan mencit Balb/C yang diinduksi STZ, dikelompokkan dalam 4 grup yaitu luka diabetes tanpa treatment $(\mathrm{N})$, luka diabetes dengan treatment spray $A$. vera $1 \%$ (Av), luka diabetes dengan treatmen plasma jet non thermal dengan jarak paparan $20 \mathrm{~mm}$ selama 3 menit $(\mathrm{P})$ dan luka diabetes dengan treatment kombinasi spray A. vera $1 \%$ dan plasma jet non thermal dengan jarak paparan $20 \mathrm{~mm}$ selama 3 menit (PAv). Spray larutan A. vera 1\% terdiri dari ekstrak A. vera, DMSO dan aquabidest. Terapi dilakukan selama 14 hari. Evaluasi data kadar malondialdehid dan profil darah dianalisis menggunakan One Way Anova yang dilanjutkan uji Post Hoc Tukey. Evaluasi rasio luas luka dianalisis menggunakan repeated anova. Hasil kadar glukosa darah menunjukkan sebelum eksperimen yaitu $241,74 \mathrm{mg} / \mathrm{dL} \pm 51,99$. Kombinasi plasma jet non thermal dan sediaan spray larutan $A$. vera $1 \%$ dapat menurunkan kadar malondialdehid $(\mathrm{p}<0,05)$ namun tidak signifikan dalam mengecilkan rasio luas luka $(\mathrm{p}>0,05)$ dan tidak signifikan dalam mempengaruhi profil darah $(\mathrm{p}>0,05)$. Temuan menunjukkan bahwa kombinasi plasma jet dan sediaan spray larutan $A$. vera $1 \%$ dapat menurunkan kadar malondialdehid pada luka diabetes.
\end{abstract}

Kata kunci: spray A. vera, plasma jet non thermal, luka diabetes, malondialdehid, rasio luas luka, profil darah

\section{ABSTRACT}

Plasma jet non thermal has benefit in wound healing, but less control can to accumulation of reactive oxygen species. This study aims to determine the effectiveness of the combination of plasma jet and A. vera spray $1 \%$ for wound 
Jurnal Ilmiah Ibnu Sina, 6(2), Oktober 2021, 232-241

p-ISSN: 2502-647X; e-ISSN: 2503-1902

healing in diabetic wounds mice model with parameters of malondialdehyde levels, the skin wound ratio, and blood profile. This study used male Balb/C were induced by a streptozotocin (STZ) and divided into 4 groups, namely groups of untreated diabetic mice wounds $(N)$, groups of diabetic mice wound with A. vera spray $1 \%(A v)$, groups of diabetic mice wound with plasma jet non thermal at distance of $20 \mathrm{~mm}$ for 3 minutes $(P)$, and groups of diabetic mice wound with plasma jet non thermal at distance of $20 \mathrm{~mm}$ for 3 minutes and A. vera spray $1 \%$ (PAv). The solution of A. vera spray $1 \%$ preparation consists of A. vera, DMSO, and aquabidest extracts. The wounds of all groups treated for 14 days then the malondialdehyde, skin wound ratio and blood profile were calculated by SPSS Statistic. The results of blood glucose before treatment were $241.74 d L \pm 51.99$. The combination of plasma jet and A. vera spray $1 \%$ groups were significant ( $p$ $<0.05)$ in reduce malondialdehyde levels, reduced the the skin wound ratio but not different significantly ( $p>0.05)$, and not effect on blood profile data ( $p>0.05)$. In conclusion, A. vera spray $1 \%$ can reduce the side effects of plasma jet in diabetic wounds by reducing malondialdehyde levels.

Keywords: $A$. vera $1 \%$ spray, plasma jet non thermal, diabetic wounds, malondialdehid, the skin wound ratio, blood profile.

\section{PENDAHULUAN}

Berdasarkan data Riskesdas 2019, Indonesia menempati urutan ke-7 terbesar dengan jumlah penderita terbanyak yaitu 10,7 juta. Tingginya kadar gula darah menyebabkan aktivitas neutrofil yang berlebih menghasilkan produksi reactive oxygen spesies (ROS) yang merusak elemen struktural dari ECM (extra cellular matrix) dan sel membran serta meningkatkan malondialdehid (Subandrate, 2016). Malondialdehid adalah salah satu produk akhir dari peroksidasi lipid. Pengukuran kadar malondialdehid (MDA) dilakukan untuk melihat jumlah radikal bebas yang berkaitan dengan peroksidasi lipid. Laporan oleh Subandrate (2016), terjadi peningkatan kadar malondialdehid pada pasien diabetes dibandingkan kelompok kontrol atau pasien tidak diabetes.

Plasma jet adalah inovasi teknologi dan bukan plasma darah tetapi lebih pada gas yang terionisasi atau disebut materi ke empat setelah padat, cair dan gas. Plasma jet terbukti mempercepat penyembuhan luka melalui perekrutan neutrofil, produksi faktor pertumbuhan, dan promosi angiogenesis (Xu dkk, 2020). Efektivitas plasma jet menggunakan gas argon pada studi in vivo menunjukkan bahwa 
perawatan luka menggunakan plasma jet selama 14 hari mempercepat penyembuhan luka akut pada tikus (Nasruddin et al., 2014). Plasma jet juga berpengaruh pada jumlah trombosit, dimana semakin lama waktu pemaparan maka waktu pembekuan menurun (Hussein dan Yousif, 2018).

Menurut Nasruddin dkk (2014), perawatan luka dengan menggabungkan plasma jet dengan senyawa dalam fase cair atau plasma activated water mampu mengurangi dampak negatif karena paparan plasma. Jarak dan lama paparan plasma jet mempengaruhi efek teraupetik dalam penyembuhan luka (Nurani dkk, 2020). Tanaman A. vera dilaporkan mampu menurunkan kadar malondialdehid pada penelitian luka akut (Yadav dkk, 2012) serta mempunyai aktivitas penyembuhan luka akut pada tikus (Sikumbang dkk, 2020). Penelitian oleh Nasruddin dkk, (2014) bahwa sediaan gel yang mengandung $A$. vera mampu mengurangi inflamasi, memperbaiki re-epitalisasi pada tikus dengan model luka diabetes.
Terkait mekanisme lebih lanjut, perlu dilakukan penelitian terkait $A$. vera dan efeknya terhadap profil darah melalui pemberian topikal. Sediaan spray larutan A. vera $1 \%$ dibuat untuk memenuhi fase liquid, sehingga diharapkan dapat mengoptimalkan kinerja plasma jet dan mengurangi efek samping dari paparan plasma jet, dapat menurunkan jumlah radikal bebas dan mempercepat penyembuhan luka diabetes. Larutan A. vera diaplikasikan dalam sediaan spray dipilih karena praktis penggunaanya, terkontrol, dan tidak perlu bersentuhan langsung dengan luka sehingga lebih higenis.

\section{METODE PENELITIAN}

\section{Alat}

Alat yang digunakan adalah alat-alat gelas kaca (Iwaki pyrex), plasma jet non-thermal, kamera digital (Lumix Panasonic), microtube, seperangkat alat bedah, timbangan analitik, punch biopsi $4 \mathrm{~mm}$, pencukur rambut (Kemei), glucometer (Easytouch), needle G25, hematology analyzer (Sysmax), spektrofotometer

UV-Vis 
Jurnal Ilmiah Ibnu Sina, 6(2), Oktober 2021, 232-241

p-ISSN: 2502-647X; e-ISSN: 2503-1902

(Shimadzu), lembar polypropilen bening (PP Sheets), microtube.

\section{Bahan}

Bahan yang digunakan dalam adalah Aloe vera, streptozotocin (Nacalai Tesque), ketamin, xylazin, larutan $\mathrm{NaCl}$ fisiologis $0,9 \%$ (Otsuka), gas argon, glukosa (Merck), larutan EDTA (BDH), hydrocolloid dressing (Tegaderm), Water for Injection (WFI), buffer formalin 10\% (Surgipath), dimetil sulfoksida (Merck), aquabidest (Otsuka), broth, $\mathrm{KCl} 1,15 \%$, sodium dodesil sulfat $8,1 \%$, reagen asam tiobarbiturat $0,8 \%$, n-butanol, piridine dan TEP (1,1,3,3-tetraetoksipropan).

\section{Prototipe Plasma Jet}

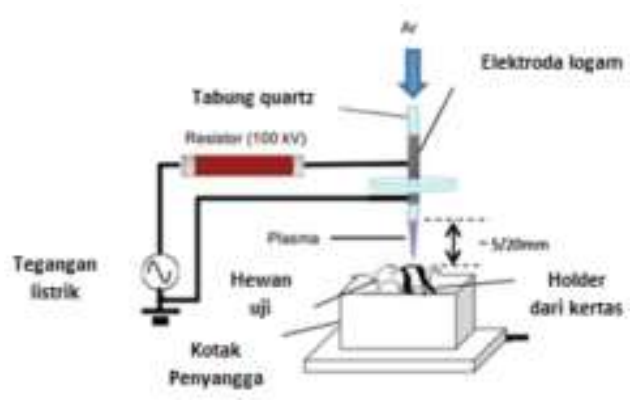

Gambar 1. Skema alat prototipe teknologi plasma jet

Prototipe plasma jet telah dipakai dalam beberapa penelitian sebelumnya yang telah dipublikasikan oleh (Darmawati dkk,
2019; Nurani dkk, 2020) seperti yang terlihat pada pada Gambar 1.

\section{Pembuatan Ekstrak}

Ekstraksi dengan maserasi menggunakan alkohol 70\% selama 3 jam. Maserat dipekatkan menggunakan rotary evaporator dan dikeringkan dengan freeze dryer (Prakoso, 2018).

\section{Induksi Streptozotocin pada}

\section{Hewan Percobaan}

Mencit jantan galur Balb/C diaklimatisasi, dipuasakan selama 12 jam, ditimbang dengan rata-rata berat badan $31,58 \mathrm{~g} \pm 3,42$. Sampel darah hewan diambil dari ekor vena untuk mengetahui kadar glukosa awal. Selanjutnya hewan diinjeksi dengan streptozotocin dosis tinggi tunggal $100 \mathrm{mg} / \mathrm{kgBB}$ yang dilarutkan dalam buffer sitrat dengan konsentrasi 0,01 $\mathrm{M} \mathrm{pH}$ 4,5 secara intraperitoneal (i.p) (Deeds dkk, 2011). Pada hari ke-14 setelah injeksi dilakukan pengukuran kadar gula darah. Kelayakan etik diperoleh dari LPPT UGM, Yogyakarta Indonesia (Nomor sertifikat 00004/04/LPPT/III/2018). 
Jurnal Ilmiah Ibnu Sina, 6(2), Oktober 2021, 232-241

p-ISSN: 2502-647X; e-ISSN: 2503-1902

\section{Pembuatan Sediaan Spray Larutan}

\section{A. vera}

Spray larutan A. vera dibuat dengan melarutkan sebayak $1 \mathrm{~g}$ ekstrak $A$. vera ke dalam pelarut DMSO kemudian ditambahkan aquabidest hingga $100 \mathrm{~mL}$. Menurut (Damayanti dan Yuwono, 2014), pelarut DMSO memiliki potensi sebagai enhancer yang besar terhadap permeasi teofilin menembus membran kulit tikus.

\section{Perlakuan pada Hewan Uji}

Pengujian dengan mencit jantan galur Balb/C terbagi atas 4 kelompok dengan 5 ekor mencit tiap kelompok. Kelompok tersebut adalah kelompok N (kontrol luka diabetes), kelompok Av (luka diabetes + spray larutan A. vera 1\%), P (luka diabetes + plasma jet non thermal dengan paparan $20 \mathrm{~mm}$ selama 3 menit), dan Pav (luka diabetes+ spray larutan A. vera $1 \%+$ plasma jet non thermal dengan paparan $20 \mathrm{~mm}$ selama 3 menit).

\section{Evaluasi Kadar Malondialdehid} (MDA)

Bahan uji yang digunakan berupa kulit yang mengalami injury, dan pengambilan kulit dilakukan empat belas hari seperti yang dilakukan oleh Widyaningsih dkk, (2015). Kadar MDA pada kulit dinyatakan dalam nmol MDA/gram organ.

\section{Evaluasi Rasio Luas Luka}

Pembuatan luka dilakukan pada hari ke 0 dan proses penyembuhan luka diamati setiap hari selama 14 hari. Luas luka dihitung dengan software analisis Scion Image Beta 4.02. Rasio luas luka dibandingkan antara luas luka pada dorsal kanan dan kiri. Luas luka dihitung dengan persamaan berikut:

Rasio Luas Luka $=\frac{\text { Luas luka hari ke-n }}{\text { Luas luka hari ke-1 }}$.

(Nasruddin dkk, 2014)

\section{Evaluasi Profil Darah}

Darah diambil dari retro orbital plexus sebanyak $0,5 \mathrm{~mL}$ untuk pengukuran darah rutin. Pemeriksaan profil darah dilakukan menggunakan hematology analyzer sysmax (alat otomatis). Hematology analyzer bekerja dengan prinsip flowcytometer (Keohane dkk, 2015).

\section{Analisis Data}

Analisis data yang digunakan untuk kadar malondialdehid, rasio luas luka pada kulit, dan profil darah 
Jurnal Ilmiah Ibnu Sina, 6(2), Oktober 2021, 232-241

p-ISSN: 2502-647X; e-ISSN: 2503-1902

pada seluruh kelompok perlakuan,

Hasil menunjukkan bahwa dianalisis dengan metode ANOVA menggunakan software IBM SPSS Statistics 20.0.

\section{HASIL DAN PEMBAHASAN}

\section{Ekstrak etanol A. vera}

Ekstrak etanol A. vera diperoleh dari daun $A$. vera dengan rendemen 24,876 \%. Pengujian kadar air menunjukkan hasil kadar air ekstrak sebesar $8,99 \% \quad(<10 \%)$ (PerkaBPOM, 2019).

\section{Kadar Malondialdehid dan Profil Darah}

Kadar malondialdehid dan profil darah pada kelompok uji terlihat pada Tabel 2 .

Tabel 2. Kadar MDA dan profil darah pada mencit diabetes, spray A. vera, plasma jet dan kombinasi spray

\begin{tabular}{lllll}
\multicolumn{5}{c}{ A. vera dan plasma jet } \\
\cline { 2 - 5 } KLPK & \multicolumn{4}{c}{ Rerata \pm SD } \\
& $\mathbf{N}$ & $\mathbf{A v}$ & $\mathbf{P}$ & PAv \\
\hline MDA & 2,48 & $1,14 \pm$ & $3,76 \pm$ & $0,55 \pm$ \\
$(\mathrm{nmol} / \mathrm{g})$ & \pm 0, & $0,12^{*}$ & $0,27^{*}$ & $0,17^{*}$ \\
& 2 & & & \\
$\mathrm{WBC}$ & 3,5 & $3,1 \pm 0$ & $4,5 \pm 0$ & $3,2 \pm 1$ \\
$\mathrm{x} 10^{3 / \mu 1}$ & \pm 2, &, 52 &, 79 & 47 \\
& 25 & & & \\
$\mathrm{RBC}$ & 7,8 & $6,5 \pm 0$ & $5,4 \pm 0$ & $6,5 \pm 1$ \\
$\mathrm{x} 10^{6 / \mu 1}$ & \pm 0, &, $42^{*}$ &, $56^{*}$ & 05 \\
& 91 & & & \\
$\mathrm{PLT}$ & 600, & 406,0 & 471,5 & 590,2 \\
$\mathrm{x} 10^{3 / \mu 1}$ & $2 \pm 7$ & $\pm 77,9$ & \pm 194, & \pm 184 \\
& 8,64 & 8 & 23 & 98 \\
\hline
\end{tabular}

kelompok PAv signifikan dalam mengurangi kadar MDA dibandingkan kelompok $\mathrm{N}(\mathrm{p}<0,05)$, sedangkan kelompok $\mathrm{P}$ signifikan dalam meningkatkan kadar MDA $(\mathrm{p}<0,05)$, artinya plasma jet selain dapat menyembuhkan luka, juga dapat menyumbangkan ROS. Tanaman A. vera terkonfirmasi berperan dalam penyembuhan luka (Hekmatpou dkk, 2019; Prakoso, 2018). Menurut Woedtke (2019), adanya kombinasi plasma jet dan sediaan cair dapat mempertahankan efek plasma biologis ketika ditambahkan antioksidan melalui reaksi redoks pada jalur Nrf2.

Hasil menunjukkan bahwa kelompok $\mathrm{P}$ memiliki jumlah sel darah putih terbesar, sedangkan kelompok Av dan PAv memiliki jumlah sel darah putih mendekati kelompok kontrol (N), artinya adanya paparan plasma jet berkontribusi dalam penambahan neutrofil dan adanya spray A. vera $1 \%$ mampu mengurangi jumlah neutrofil akibat kondisi hyperglikemik dan paparan plasma jet. Penelitian ini sama dengan laporan oleh (Xu dkk, 
Jurnal Ilmiah Ibnu Sina, 6(2), Oktober 2021, 232-241

p-ISSN: 2502-647X; e-ISSN: 2503-1902

2020), dimana plasma jet peradangan terjadi pada hari ke-3 mempercepat penyembuhan luka melalui perekrutan neutrofil. Hasil uji statistik Kruskal Wallis menunjukkan bahwa terjadi kenaikan dan penurunan yang tidak signifikan pada WBC dan PLT pada kelompok luka DM. Namun demikian pada kelompok pemberian sediaan spray $A$. vera $1 \%$ tunggal (Av) dan pemberian paparan plasma jet tunggal dengan jarak $20 \mathrm{~mm}$ selama 3 menit, signifikan dapat menaikkan RBC. Penelitian oleh Nku dkk, (2014), pemberian gel $A$. vera signifikan dapat meningkatkan jumlah RBC pada kelompok tikus kronis.

\section{Rasio Luas Luka}

Evaluasi rasio luas luka menunjukkan bahwa keseluruhan kelompok memiliki pola penyembuhan luka yang tidak berbeda jauh. Tidak terdapat perbedaan yang signifikan antara kelompok PAv dan P dibandingkan kelompok $\mathrm{N}$ (p>0,05), sedangkan kelompok Av menunjukkan perbedaan yang signifikan dibandingkan kelompok $\mathrm{N}(\mathrm{p}<0,05)$. Grafik rasio luas luka dapat dilihat pada Gambar 4, terlihat fase hingga hari ke-6. Pada hari ke 6, 7, dan 8 .

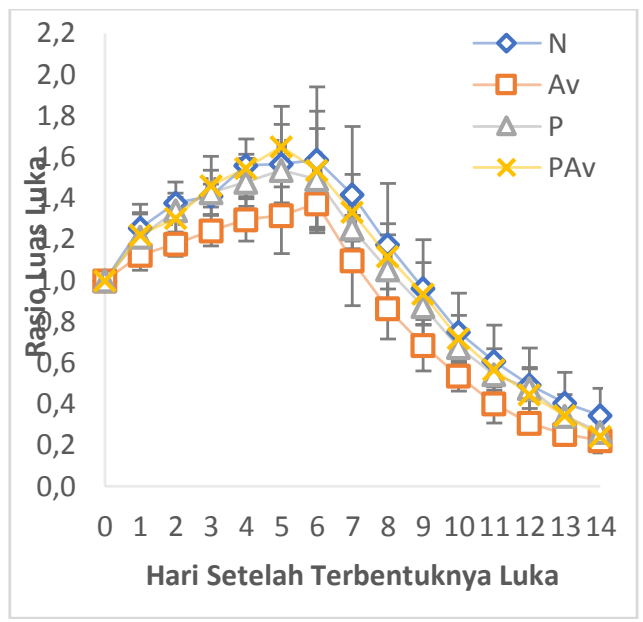

Gambar 4. Grafik Rasio Luas Luka

Hasil pengamatan makroskopik dapat dilihat pada Gambar 5, terlihat pada hari ke-14 luka sudah mulai menutup.

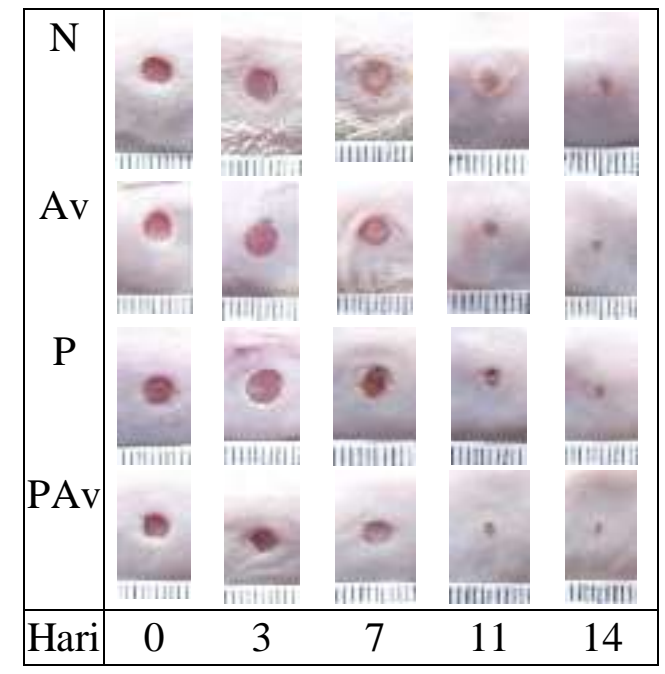

Gambar 5. Observasi maksroskopik pada hari ke-0, 3, 7, 11, dan 14

Kelompok PAv mampu mengecilkan rasio luas luka, 
Jurnal Ilmiah Ibnu Sina, 6(2), Oktober 2021, 232-241

p-ISSN: 2502-647X; e-ISSN: 2503-1902

sedangkan kelompok Av memiliki ukuran rasio luas luka terkecil namun memiliki kadar MDA lebih besar daripada kelompok PAv. Hekmatpou dkk, (2019) melaporkan bahwa $A$. vera memiliki kemampuan sebagai agen wound healing, dapat menghambat reaksi inflamasi dengan cara penghambatan IL-6 dan IL-8, penurunan adhesi leukosit, peningkatan kadar IL-10, dan penurunan kadar alfa TNF.

\section{KESIMPULAN}

Kombinasi paparan plasma jet dan sediaan spray $A$. vera $1 \%$ signifikan dapat menurunkan kadar malondialdehid pada luka diabetes, dapat menurunkan rasio luas luka namun tidak signifikan dan tidak signifikan dalam mempengaruhi profil darah (RBC, HGB, PLT dan WBC).

\section{UCAPAN TERIMA KASIH}

Terima kasih saya ucapkan kepada LPPM UAD dan team peneliti dari laboratorium plasma medis UM Magelang.

\section{DAFTAR PUSTAKA}

Damayanti, R. A., \& Yuwono, T. (2014). Dimetilsulfoksid Sebagai Enhancer Transpor Transdermal Teofilin Sediaan Gel. Pharmaciana, 3(1), 66-68.

Darmawati, S., Rohmani, A., Nurani, L. H., Prastiyanto, M. E., Dewi, S. S., Salsabila, N., ... Nasruddin, N. (2019). When plasma jet is effective for chronic wound bacteria inactivation, is it also effective for wound healing? Clinical Plasma Medicine, 14(18), 100085. https://doi.org/10.1016/j.cpme.2 019.100085

Deeds, M. C., Anderson, J. M., Armstrong, A. S., Gastineau, D. A., Hiddinga, H. J., Jahangir, A., ... Kudva, Y. C. (2011). Single dose streptozotocininduced diabetes: Considerations for study design in islet transplantation models. Laboratory Animals, 45(3), 131-140. https://doi.org/10.1258/la.2010. 010090

Haritha Yadav, K. C., Ravi Kumar, J., Basha, I. I., Deshmukh, G. R., Gujjula, R., \& Santhamma, B. (2012). Wound healing activity of topical application of Aloe vera gel in experimental animal models. International Journal of Pharma and Bio Sciences, $3(2), 66-67$.

Hekmatpou, D., Mehrabi, F., Rahzani, K., \& Aminiyan, A. (2019). The effect of aloe vera clinical trials on prevention and healing of skin wound: A systematic review. Iranian 
Jurnal Ilmiah Ibnu Sina, 6(2), Oktober 2021, 232-241

p-ISSN: 2502-647X; e-ISSN: 2503-1902

Journal of Medical Sciences, 44(1), 3-7.

Hussein, M. U., \& Yousif, E. S. (2018). Mechanism of Platelets Stimulation by Non Thermal Plasma. International Journal of Chinese Medicine, 2(February), 1-5. https://doi.org/10.11648/j.ijcm.2 0180201.11

Keohane, E. M., Smith, L., \& Walenga, J. M. (2016). Rodak's Hematology: Clinical Principles and ApplicationsNo Title (Edisi ke-5). Elsevier 232-234.

Nasruddin, Nakajima, Y., Mukai, K., Setyowati, H., Rahayu, E., Sugama, J., \& Nakatani, T. (2014). Cold plasma on fullthickness cutaneous wound accelerates healing through promoting in $\mathrm{fl}$ ammation, reepithelialization and wound contraction. Clinical Plasma Medicine, 2(1), 28-35. https://doi.org/10.1016/j.cpme.2 014.01.001

Nku, C. O., Ofem, O. E., \& Okon, U. A. (2014). Effect of prolong consumption of crude Aloe barbadensis (Aloe vera) gel on haematological indices in rats. Asian Journal of Medical Sciences, 6(2), 58-60. https://doi.org/10.3126/ajms.v6i 2.11106

Nurani, L. H., Nasruddin, N., Darmawati, S., \& Wahyuningtyas, E. S. (2020). Plasma Jet - Treated Lidah Buaya (Aloe Vera) Influences Proliferative-Phase Wound Healing. Plasma Medicine, 10(2), 123-138.
Perka BPOM. (2019). Persyaratan Keamanan dan Mutu Obat Tradisional. Badan Pengawas Obat dan Makanan Republik Indonesia Hal 22-23, 16-17.

Prakoso, Y. A. (2018). The Effects of Aloe vera Cream on the Expression of CD4 + and CD8 + Lymphocytes in Skin Wound Healing, 2018.

Sikumbang, I. M., Astuti, R. A., Wahyuningtyas, E. S., Lutfiyati, H., Wijayatri, R., \& Nasruddin, N. (2020). Wound healing activity of aloe vera extract spray on acute wound in male $\mathrm{balb} / \mathrm{c}$ mice. Pharmaciana, 10(3),

315. https://doi.org/10.12928/pharma ciana.v10i3.16640

Subandrate. (2016). Hubungan Kadar Glukosa Darah dengan Peroksidasi Lipid pada Pasien Diabetes Melitus tipe 2. Departemen Biokimia Fakultas Kedokteran Universitas Sriwijaya, 43(7), 487-489.

Von Woedtke, T., Schmidt, A., Bekeschus, S., Wende, K., \& Weltmann, K. D. (2019). Plasma medicine: A field of applied redox biology. In Vivo, 33(4), 1011-1026. https://doi.org/10.21873/invivo. 11570

Wahyuningtyas, E. S., Setyowati, H., Rahayu, E., \& Lutfiyati, H. (2020). Efek Perlakuan Kombinatif Plasma Medis dan Ekstrak Daun Binahong Terhadap Penyembuhan Luka Fase Proliferasi Pada Mencit Diabetik. University Research Colloqium, 238, 239-240. 
Jurnal Ilmiah Ibnu Sina, 6(2), Oktober 2021, 232-241

p-ISSN: 2502-647X; e-ISSN: 2503-1902

Widyaningsih, W., Sativa, R., \& Primardiana, I. (2015). Efek Antioksidan Ekstrak Etanol Ganggang Hijau (Ulva Lactuca L.) Terhadap Kadar Malondialdehid (MDA) Dan Aktivitas Enzim Superoksida Dismutase (SOD) Hepar Tikus Yang Diinduksi CCL4. Media Farmasi: Jurnal Ilmu Farmasi, 12(2), 168-169. https://doi.org/10.12928/mf.v12 i2.3756

Xu, D., Wang, S., Li, B., Qi, M., Feng, R., Li, Q., \& Zhang, H. (2020). E ff ects of PlasmaActivated Water on Skin Wound Healing in Mice. Microorganisms, 8, 2-14. 